\title{
LUT
}

University

\section{Separation or integration of journalistic and business responsibilities? Corporate responsibility in Finnish media companies}

\author{
Olkkonen Laura
}

This is a Author's accepted manuscript (AAM) version of a publication published by Taylor \& Francis

in Journal of Media Business Studies

DOI: $10.1080 / 16522354.2018 .1496554$

Copyright of the original publication: (c) 2018 Informa UK Limited

Please cite the publication as follows:

Laura Olkkonen (2018) Separation or integration of journalistic and business responsibilities? Corporate responsibility in Finnish media companies, Journal of Media Business Studies, 15:3, 169-187, DOI: 10.1080/16522354.2018.1496554

This is a parallel published version of an original publication. This version can differ from the original published article. 
Olkkonen, Laura. (2018). Separation or integration of journalistic and business responsibilities? Corporate responsibility in Finnish media companies. Journal of Media Business Studies, Vol. 15, No 3, pp. 169-187.

This is an Accepted Manuscript of an article published by Taylor \& Francis in Journal of Media Business Studies on July 17, 2018, available online:

http://www.tandfonline.com/10.1080/16522354.2018.1496554. **Please cite as above**

\begin{abstract}
Not only do media organisations serve a societal role, they also influence societies through their behaviour as businesses. Therefore, the full range of the responsibilities of media organisations extends to include issues of both journalism ethics and business ethics. This article examines sector-based corporate responsibility as a way to integrate journalistic and business responsibilities. Empirically, the article examines how journalistic and business responsibilities unfold in large Finnish media companies. The analysis shows that 'dual thinkers’ narrow corporate responsibility only to environmental issues and, consequently, fail to address large areas of social responsibility, whereas 'integrative forerunners' make meaningful connections between journalistic and business responsibilities. For media managers, the article offers insights into how sector-based corporate responsibility can weave industry-specific responsibilities into general corporate responsibility issues.
\end{abstract}

Keywords: media responsibility; corporate responsibility; journalism ethics; business ethics; sector-based corporate responsibility 
Olkkonen: Separation or integration of journalistic and business responsibilities

\section{Introduction}

Media organisations serve an important societal role by making sense of current issues and events, but their influence on societies extends into how they behave as businesses. The operating environment for contemporary media organisations is increasingly market-driven, and media professionals increasingly work for large and conglomerated companies, which have both priorities and responsibilities as business entities (Richards, 2004; Stern, 2008). Essentially, as media organisations become more complex, their scope of influence encompasses ever larger groups of stakeholders, including their audiences, communities, employees, owners, partners, sources and funders, such as advertisers (Martin \& Souder, 2009; Richards, 2004). Thus, as businesses, media organisations and their production processes generate economic, social and environmental impacts on their customers, the people they employ, the partners they work with and the communities in which they are embedded (Richards, 2004).

The increasing complexity around media organisations is a typical reason for intensifying expectations of accountability and responsibility: when the power of corporations increases, expectations are heightened to balance the influence and control (e.g. Banerjee, 2008). The scale of the complexity also means that the actions of a single company become more difficult to assess, as the operations expand and can become intertwined in multifaceted production chains (Tate, Ellram, \& Kirchoff, 2010). Scandals and negative trends are another typical reason for increased expectations of responsibility (Matten \& Moon, 2008), which, in the case of media can relate to such topical issues as privatisation and globalisation (Karmasin \& Bichler, 2017), click-baiting (Nygaard Blom \& Reinecke Hansen, 2015), privacy (Gershon \& Alhassan, 2017; Wring, 2012) and the use of big data (Fairfield \& Shtein, 2014). Essentially, the current ethical challenges faced by media organisations do not only concern questions of journalism ethics, but also of business ethics, management 
Olkkonen: Separation or integration of journalistic and business responsibilities

practices as well as organisational culture and conduct, as demonstrated, for example, by the News of the World phone-hacking scandal (Gershon \& Alhassan, 2017).

This article examines the responsibilities of media organisations from a holistic perspective and departs from a seeming tension stemming from a long-standing ideal of separating democratic and journalistic ideals from commercial goals (Commission on Freedom of the Press, 1947; Peterson, 1956). The article explores this separation argument in contrast to the much newer concept of corporate responsibility, which suggests that all businesses, regardless of the industry in which they operate, have responsibilities that relate directly to how they operate and who they influence with their operations (Freeman, 1984; Matten \& Moon, 2008; Schrempf, 2012). Corporate responsibility, especially when understood as sector-based corporate responsibility, is a comprehensive view of the responsibilities of media companies as a combination of journalistic and business responsibilities. Therefore, it can serve as a possible solution to resolving the tension between journalistic ideals and business goals.

This article is situated in an emerging stream of research that discusses responsibilities and ethics in the media sector not only as media ethics and journalism ethics, but also as combined economic, social and environmental business responsibilities (for other examples, see Bachmann \& Ingenhoff, 2017; Ingenhoff \& Koelling, 2012; Karmasin \& Bicher, 2017; Olkkonen, 2015). The entwinement of different responsibilities is supported by a recent study, which found that people do not view media organisations' journalistic and business responsibilities separately; rather, the actions of media organisations, whether they relate to editorial decisions or business decisions, are assessed as a whole, and they both contribute to how responsible an organisation is perceived (Olkkonen, 2015). Thusalthough perhaps convenient from a management perspective-attempts to separate journalistic and business responsibilities might not make the conduct of media organisations 
Olkkonen: Separation or integration of journalistic and business responsibilities

clearer or more reliable for the stakeholders who assess it, but actually fuzzier and more difficult to assess. In this process, media organisations might lose important opportunities to create value and maintain credibility.

The next section introduces the separation argument as a dual responsibility view to media organisations’ responsibilities, followed by a section on integrative, sector-based corporate responsibility for media organisations. The article then moves on to present an empirical study from Finland, where the media sector is affected by concerns of growing market pressures and consequent eroding ethics, despite Finland’s well-integrated professional norms (Heikkilä \& Kylmälä, 2011; Karppinen, Nieminen, \& Markkanen, 2011) and top rankings in the World Press Freedom Index (Reporters Without Borders, 2018). For example, journalistic principles and methods in Finnish crisis reporting have been scrutinised for their ethical soundness (Raittila et al., 2010); the exposure of privacy has been seen as a threat to responsible media conduct (Wilenius \& Malmelin, 2009); and recently, the media’s independence from political pressures has been questioned (Reporters Without Borders, 2016). The empirical study is an example of how media organisations engage in corporate responsibility and, in the process, make their own interpretations of responsibility in the media sector. The data consists of corporate reports and website material from five large Finnish media companies. The research questions guiding the analysis are: (1) How do large Finnish media companies address corporate responsibility? and (2) Do large Finnish media companies separate or integrate journalistic and business responsibilities?

As the analysis shows, some of the companies integrate journalistic and business responsibilities, while others make a clear separation and do not address anything journalismrelated in their responsibility materials. Based on the analysis, the companies are categorised as 'dual thinkers', 'semi-integrative' or 'integrative forerunners' on the basis of their stance 
Olkkonen: Separation or integration of journalistic and business responsibilities

on corporate responsibility. The article ends with a discussion on the implications of separating and integrating the responsibilities of media organisations.

\section{The Separation Argument: Journalism and Business as Separate Areas}

The argument for separating democratic and journalistic ideals from the business side of media production dates long ago, as it was central to the first conceptualisations of the social responsibility of the media in the 1940s and 1950s (Commission on Freedom of the Press, 1947; Peterson, 1956). In the famous report of the Commission on Freedom of the Press (1947), the social responsibility of the media or, as then stated, 'the press', had to do with preserving democratic and journalistic ideals such as providing a truthful, comprehensive and intelligent report on events, safeguarding individual rights, enlightening the public and separating these ideals from commercial goals (see also McIntyre, 1987; Peterson, 1956).

In the initial stages, social responsibility theory (Peterson, 1956) did not recognise responsibilities beyond journalism—-that is, there were no responsibilities that were seen to relate to running a business. However, business responsibilities have more recently been addressed, for example, by Adams-Bloom and Cleary (2009), who have suggested a dual responsibility model for media organisations, whereby social responsibilities to the audience are balanced in relation to financial responsibilities to shareholders. The dual responsibility model draws on stakeholder theory, which is one of the most utilised theories when studying corporate responsibility (Freeman, 2004; Crane \& Glozer, 2016). The central idea of stakeholder theory is acknowledging stakeholders as groups or entities that have some sort of a stake or interest in the operations of a focal organisation and finding ways to balance these interests (Freeman, 1984). Originally coined by Freeman (1984), a stakeholder is any group that can affect or is affected by the organisation, and hence, a stakeholder does not necessarily have economic interests. What Adams-Bloom and Cleary (2009) suggest is a 
Olkkonen: Separation or integration of journalistic and business responsibilities

revision of social responsibility theory by dividing the responsibilities of media organisations into financial responsibility to shareholders and social responsibility to audiences. They claim that this conceptualisation more accurately captures the logic in which editorial decisions are made in current media environment — the guiding question for selecting and prioritising content is not only whether it is important, but also whether it will actually be consumed by the target audience (Adams-Bloom \& Cleary, 2009, p. 6).

Though acknowledging dual responsibilities of both journalism and business is an attempt to simultaneously address the editorial and financial motives of news production, this acknowledgement does not recognise ethical dimensions outside the scope of editorial management; rather, the business side is seen only as an economic responsibility to one stakeholder: shareholders. Moreover, economic concerns are often contrasted with ethical concerns (e.g. Adams-Bloom \& Cleary, 2009; Martin \& Souder, 2009), which implies that journalism needs protection from (unethical) business thinking. Furthermore, the separation argument often insufficiently addresses organisation-level responsibilities, as ethics in the media is most often discussed on the level of the individual journalists who should bear responsibility to their public, their sources and their own integrity (e.g. Christians \& Nordenstreng, 2004; Hayes, Singer, \& Ceppos, 2007; Peterson, 1956; Richards, 2004). Essentially, what is missing is the lens of business ethics in relation to economic, social and environmental responsibilities.

The next section presents a holistic view of the responsibilities of media organisations beyond the separation argument. From the perspective of sector-based corporate responsibility, the in-built tension between journalism and business in the separation argument is artificial, as both spheres of responsibility (journalism and business) are part of the overall corporate responsibility of media organisations. A comprehensive view of media organisations' responsibilities is not an attempt to discard the intrinsic duality that sets media 
Olkkonen: Separation or integration of journalistic and business responsibilities

organisations apart from other business organisations: they do entail editorial management and business management, and they do serve societal and business purposes (cf. Altmeppen, Hollifield, \& van Loon, 2017). However, sector-based corporate responsibility allows the examination of dual responsibilities as the unique mix of responsibilities that are relevant for the media sector, as all industries have characteristics that set them apart from other industries. The next section explains this further.

\section{The Integrative Argument: Journalism Ethics and Business Ethics as Sector-Based}

\section{Corporate Responsibility}

The business ethics of an organisation stems from the principles, values and norms that guide organisational conduct (Ferrell, Fraedrich, \& Ferrell, 2015). Corporate responsibility entails responsibilities that rely on business ethics: the role of moral problems and moral judgements in business situations, activities and decisions in both internal (e.g. concerning employees) and external (e.g. concerning the natural environmental) settings (e.g. Crane \& Matten, 2007). Ethics is what guides corporate responsibility, which in turn depends on the societal and environmental impacts of business and the societal role of business organisations (Okoye, 2009). Corporate responsibility can be understood as responsibilities that business organisations have for (the rest of the) society or as a reflection of social imperatives and the social consequences of business (Matten \& Moon, 2008). To differentiate between various ways of understanding corporate responsibility (or adjacent concepts such as corporate social responsibility (CSR) or corporate citizenship; see Amaeshi \& Adi, 2007), distinctions can be made between the instrumentalist/positivist view (corporate responsibility as value creation), the normative view (corporate responsibility as moral evaluation) and the political view (corporate responsibility as political engagement) (Scherer \& Palazzo, 2007). 
Olkkonen: Separation or integration of journalistic and business responsibilities

Schrempf (2012) defines corporate responsibility as a responsibility that depends not only on causality and direct links between action and outcome, but also on social connections that can be indirect and more difficult to trace. Social connectivity connects with the idea of sector-based corporate responsibility, which acknowledges not only universal responsibility issues that concern any business, but also issues that vary depending on the industry or sector (e.g. Timonen \& Luoma-aho, 2010). This is due to the different-environmental and societal-impacts of different products and services that ultimately define what responsibility entails for each sector or even each organisation. These responsibilities are manifold and they deal with various stakeholders, including shareholders, employees, subcontractors, customers, and local communities. Universal or generic responsibilities include adherence to laws and regulations, environmental protection, occupational safety, and respecting human rights (Global Reporting Initiative, 2013), whereas sector-based issues depend on the operations and unique impacts of a sector, as well as the wider societal issues to which organisations operating in each sector are connected. Sector-based differences in corporate responsibility are acknowledged, for example, by the Global Reporting Initiative, which sets international standards for corporate responsibility reporting, and publishes sector-specific guidelines (Global Reporting Initiative, 2018).

Though the notion of corporate responsibility is significantly newer than media ethics and journalism ethics (Gulyás, 2011; Jaehnig \& Onyebadi, 2011), media ethics and journalism ethics can be viewed as parts of the sector-based traits that characterise corporate responsibility in the media sector (cf. Bachmann \& Ingenhoff, 2017). As sector-based corporate responsibility presents an integrative view of media organisations as producers of journalistic content and media products and as businesses that run manufacturing processes to make a profit, it potentially solves some of the tensions between journalistic ideals and business goals. Corporate responsibility does not view any area of an organisation or its 
Olkkonen: Separation or integration of journalistic and business responsibilities

actions as inherently ethical or unethical; rather, how ethical an organisation is depends on how responsibly it is able to manage its economic, societal and environmental impacts on different stakeholders.

Scholars such as Grayson (2009) and Gulyás (2011) have listed issues that are important for responsible media organisations, such as freedom of expression, impartiality, transparent editorial policies, respect for privacy, aligning corporate values and advertisers' values, the duty to educate and inform, the promotion of media literacy, diversity of output, creative independence, and valuing creativity. Both Grayson (2009) and Gulyás (2011) have also mentioned universal responsibilities that are common to all industries, such as the environmental impact of products, labour practices, human rights and community relations. In addition, Hou and Reber (2011), Ingenhoff and Koelling (2012), Jaehnig and Onyebadi (2011) and Wilenius and Malmelin (2009) have delineated different attributes that they include in the corporate responsibility of the media sector, including, for example, stewardship, media diversity, and operational transparency.

Outside academia, the Global Reporting Initiative (2014) has outlined corporate responsibility for media organisations in their media sector disclosures, where freedom of expression, information and education, pluralism and diversity, acting as a watchdog, cultural expressions and social inclusion, engagement, raising awareness on sustainability and the 'brainprint' of content are mentioned as central issues (Global Reporting Initiative, 2014, p. 8-9). In addition, the UK-based Responsible Media Forum (formerly Media CSR Forum) has suggested that the media sector deals with three types of responsibility issues: unique sector issues (e.g. transparent and responsible editorial policies, impartial and balanced output, freedom of expression); issues with special implications for the media sector (e.g. information integrity, promotion of sustainable development, citizenship); and general issues (e.g. corporate governance, climate change, customer relationships) (Media CSR Forum, 
Olkkonen: Separation or integration of journalistic and business responsibilities

2008). Resting on this tripartite division and summarising earlier literature, Table 1 presents examples of the unique sector issues for the media sector, issues with special implications for the media sector and general corporate responsibility issues that apply not only to media companies, but to business entities in general.

Table 1. Examples of Corporate Responsibility Issues in the Media Sector (adapted from Olkkonen, 2015)

\begin{tabular}{lll}
\hline $\begin{array}{l}\text { Examples of unique sector } \\
\text { issues }\end{array}$ & $\begin{array}{l}\text { Examples of issues with } \\
\text { special implications }\end{array}$ & Examples of general issues \\
\hline Editorial responsibility & Transparency & Corporate governance \\
Freedom of expression & Information integrity & Customer relationships \\
Information and education & Product responsibility & Environmental impact of \\
Pluralism and diversity & Impact of print products & products \\
Acting as a watchdog & Societal betterment & Labour practices \\
Media's brainprint & Data protection & Human rights \\
Portrayal of human rights & Digital divide & Product responsibility \\
Cultural rights & Intellectual property & Society/community relations \\
Protection of privacy & Treatment of freelancers & Environmental policies and \\
Audience & & activities \\
interaction/engagement & & Employee relations \\
Media literacy & & Stewardship \\
Responsible advertising & & Sustainable supply chain \\
Impartiality & & Staff diversity \\
Creative independence & & \\
\hline
\end{tabular}

Despite the dearth of literature on corporate responsibility in relation to media, the idea of corporate responsibility is gaining ground in media companies-especially in large, multinational companies — as Karmasin and Bichler (2017) note from their analysis of the ten largest European companies. This means that media companies are in practice engaging in corporate responsibility and, in the process, developing their own interpretations of corporate responsibility in the media sector. The empirical section presents how the current understanding of corporate responsibility unfolds in Finnish media companies. 
Olkkonen: Separation or integration of journalistic and business responsibilities

\section{Method and Data}

The data for this study consisted of corporate reports and the website material of five large Finnish media companies. The companies were selected from two listings of the largest media companies in Finland by turnover: a listing of successful companies by one of the largest business news outlets in Finland, Kauppalehti (2017), and a report on the state of the media industry by a Finnish innovation funding agency, Tekes (2009). The lists were combined to get a comprehensive selection of large, well-known and established Finnish companies that are likely to engage in corporate responsibility on some level. Public media companies were omitted from the study, as their responsibilities can differ from those of private companies. The selected companies_-Sanoma Media, Otava Group, TS Group, Keskisuomalainen Group, and Alma Media Corporation—are introduced shortly in Table 2 below. All the selected corporations produce journalistic content, which makes them relevant for this study.

Table 2. Description of the Selected Companies

\begin{tabular}{|c|c|c|c|c|c|}
\hline Company & $\begin{array}{l}\text { Document } \\
\text { analysed }\end{array}$ & $\begin{array}{l}\text { Turnover } \\
\text { (MEUR) } \\
\text { according the } \\
\text { report } \\
\text { analysed } \\
(2015)\end{array}$ & $\begin{array}{l}\text { Business areas } \\
\text { according to the report } \\
\text { analysed (2015) }\end{array}$ & $\begin{array}{l}\text { Rank in } \\
\text { Kauppalehti } \\
\text { listing } \\
\text { (2017) }\end{array}$ & $\begin{array}{l}\text { Rank in } \\
\text { Tekes } \\
\text { listing } \\
\text { (2009) }\end{array}$ \\
\hline Sanoma Media & $\begin{array}{l}\text { Online } \\
\text { Corporate } \\
\text { Social } \\
\text { Responsibility } \\
\text { Report } 2015 \\
\text { (en) } \\
\text { Code of } \\
\text { Conduct (en) }\end{array}$ & 1716,6 & $\begin{array}{l}\text { Magazines } \\
\text { Television } \\
\text { Radio } \\
\text { Online media } \\
\text { Print and electronic } \\
\text { news media } \\
\text { Print and electronic } \\
\text { learning solutions }\end{array}$ & (missing) & 1 \\
\hline Otava Group & $\begin{array}{l}\text { Annual Report } \\
2015 \text { (en), } \\
\text { Corporate } \\
\text { Responsibility } \\
\text { website (en \& } \\
\text { fi) }\end{array}$ & 292,5 & $\begin{array}{l}\text { Book publishing and } \\
\text { printing } \\
\text { Book retail } \\
\text { Magazine publishing } \\
\text { Digital services }\end{array}$ & 1 & 5 \\
\hline TS Group & $\begin{array}{l}\text { Annual review } \\
2015 \text { (fi) }\end{array}$ & 155 & $\begin{array}{l}\text { Daily newspapers } \\
\text { Local newspapers } \\
\text { Distribution services } \\
\text { Local radio }\end{array}$ & 2 & 3 \\
\hline
\end{tabular}




\begin{tabular}{|c|c|c|c|c|c|}
\hline & & & $\begin{array}{l}\text { Digital marketing } \\
\text { Printing houses } \\
\text { Maintenance services }\end{array}$ & & \\
\hline $\begin{array}{l}\text { Keskisuomalainen } \\
\text { Group }\end{array}$ & $\begin{array}{l}\text { Annual } \\
\text { Review } 2015 \\
\text { (fi), } \\
\text { Corporate } \\
\text { Responsibility } \\
\text { website (fi), } \\
\text { Environmental } \\
\text { report } 2015 \\
\text { (fi) }\end{array}$ & 149,8 & $\begin{array}{l}\text { Daily regional } \\
\text { newspapers } \\
\text { Local newspapers } \\
\text { Printing houses } \\
\text { Distribution services } \\
\text { Research services } \\
\text { Communication and } \\
\text { content agency }\end{array}$ & 3 & 11 \\
\hline $\begin{array}{l}\text { Alma Media } \\
\text { Corporation }\end{array}$ & $\begin{array}{l}\text { Annual } \\
\text { Review } 2015 \\
\text { (en), } \\
\text { Sustainability } \\
\text { website (en), } \\
\text { Code of } \\
\text { Conduct (en) }\end{array}$ & 291,5 & $\begin{array}{l}\text { Digital consumer } \\
\text { services } \\
\text { Financial media and } \\
\text { business services } \\
\text { National consumer } \\
\text { media } \\
\text { Regional media }\end{array}$ & 4 & 4 \\
\hline
\end{tabular}

Primarily English versions of the corporate reports from the year 2015 were used. However, if an English version was not provided or the material in Finnish was substantially broader, the Finnish version was included (excerpts presented in this article were translated by the author). If the company also provided corporate responsibility material online, it was included in the analysis.

The data was analysed by roughly following the process of directed (or theory-driven) qualitative content analysis (Hsieh \& Shannon, 2005). More specifically, this meant that the analysis was guided by the research questions so as to identify parts of the analysed material where the companies presented their approach to corporate responsibility and discussed responsibilities related to journalism and/or business ethics. Theory-driven analysis meant that the analysed material was reflected on earlier literature, both by utilising the ideas of the separation argument and the integration argument, and the tripartite division regarding unique sector issues, issues with special implications for the media sector, and general issues. After identifying all relevant excerpts, they were further analysed together to recognise the company's stance on the separation or integration of journalistic and business 
Olkkonen: Separation or integration of journalistic and business responsibilities

responsibilities — that is, whether they followed the separation or integration argument and what issues they listed as part of their corporate responsibility.

\section{Empirical Study: Finnish Examples of Corporate Responsibility}

The five companies reported their corporate responsibility in their reports and websites on different scales. For example, some had an extensive website and/or report dedicated to corporate responsibility issues, while others only briefly mentioned (narrow areas of) corporate responsibility in their annual report. The companies also had different stances on what they thought constituted corporate responsibility and whether they included issues that touched upon journalism ethics. Table 3 sums up the analysis by presenting each company's responsibility statements, references to journalism ethics or journalism-related responsibility issues and the most important corporate responsibility issues mentioned by the companies.

Table 3. Corporate Responsibility in Five Finnish Media Companies

\begin{tabular}{|c|c|c|c|}
\hline Company & Responsibility statement & $\begin{array}{l}\text { Examples of references to } \\
\text { journalism ethics or } \\
\text { journalism-related issues }\end{array}$ & $\begin{array}{l}\text { Most important } \\
\text { responsibility issues }\end{array}$ \\
\hline Sanoma Media & $\begin{array}{l}\text { 'Our business can be seen } \\
\text { as inherently responsible. } \\
\text { Educating, informing and } \\
\text { strengthening democracy } \\
\text { being the "watchdog” of } \\
\text { free speech all benefit } \\
\text { society.' } \\
\text { Corporate Social } \\
\text { Responsibility website, } \\
2015\end{array}$ & $\begin{array}{l}\text { '[...] we address } \\
\text { responsibility from a media } \\
\text { perspective: we honour } \\
\text { journalistic ethics, freedom } \\
\text { of speech and respect our } \\
\text { audiences by acting in a } \\
\text { trustworthy and transparent } \\
\text { manner.' } \\
\text { Corporate Social } \\
\text { Responsibility website, } \\
2015 \\
\text { 'What makes our CSR } \\
\text { efforts unique is the impact } \\
\text { we have on the lives of our } \\
\text { consumers and business } \\
\text { customers. Free media and } \\
\text { freedom of speech lays a } \\
\text { ground for democracy and } \\
\text { an open and fair society. At } \\
\text { Sanoma we've never } \\
\text { forgotten the principles that } \\
\text { our founders held sacred: }\end{array}$ & $\begin{array}{l}\text { · } \text { environmental } \\
\text { management } \\
\text { · supply chain } \\
\text { management } \\
\cdot \text { promoting democracy } \\
\text { · impact of data privacy } \\
\text { · learning and content } \\
\text { impact } \\
\text { · ethical journalism } \\
\cdot \text { talent and diversity } \\
\text { management } \\
\text { · responsible business } \\
\text { practices }\end{array}$ \\
\hline
\end{tabular}




\begin{tabular}{|c|c|c|c|}
\hline & & $\begin{array}{l}\text { free speech, fair reporting, } \\
\text { and respect for the } \\
\text { audiences by acting } \\
\text { trustworthy and } \\
\text { transparent.' } \\
\text { Corporate Social } \\
\text { Responsibility website, } \\
2015\end{array}$ & \\
\hline Otava Group & $\begin{array}{l}\text { 'The Otava Group is } \\
\text { owned by a Finnish } \\
\text { entrepreneur family. For } \\
\text { over a hundred years, the } \\
\text { Otava Group has } \\
\text { highlighted common } \\
\text { Finnish values. We want to } \\
\text { bear responsibility: to } \\
\text { promote culture, growth, } \\
\text { and learning. Fostering and } \\
\text { developing language is } \\
\text { central.' } \\
\text { Corporate responsibility } \\
\text { website, } 2015\end{array}$ & $\begin{array}{l}\text { 'In its operations, the } \\
\text { company is stable and } \\
\text { independent, and it } \\
\text { highlights freedom of } \\
\text { speech as the basis of } \\
\text { publishing operations.' } \\
\text { Corporate responsibility } \\
\text { website, } 2015\end{array}$ & $\begin{array}{l}\text { fostering the Finnish } \\
\text { culture and language } \\
\text { - learning and education } \\
\text { · well-being at work } \\
\text { · environmental } \\
\text { management in offices } \\
\text { and daily work } \\
\text { - sustainable paper } \\
\text { consumption and } \\
\text { procurement } \\
\text { - energy efficiency of } \\
\text { products }\end{array}$ \\
\hline TS Group & - & - & $\begin{array}{l}\text {. environmental } \\
\text { management }\end{array}$ \\
\hline $\begin{array}{l}\text { Keskisuomalainen } \\
\text { Group }\end{array}$ & $\begin{array}{l}\text { 'Responsibility is part of } \\
\text { the Keskisuomalainen } \\
\text { Group's values, and } \\
\text { environmental } \\
\text { responsibility is one of its } \\
\text { sub-areas.' } \\
\text { Environmental report, } 2015\end{array}$ & - & $\begin{array}{l}\text { use of materials (paper \& } \\
\text { print colour) } \\
\text {. } \mathrm{CO}^{2} \text { emissions } \\
\cdot \text { energy consumption }\end{array}$ \\
\hline $\begin{array}{l}\text { Alma Media } \\
\text { Corporation }\end{array}$ & $\begin{array}{l}\text { 'A media company's most } \\
\text { significant impact is } \\
\text { created through the content } \\
\text { it produces. Each of Alma } \\
\text { Media's media outlets } \\
\text { bears responsibility for its } \\
\text { journalistic content. Alma } \\
\text { Media's role is to promote } \\
\text { discussion on the } \\
\text { responsibility associated } \\
\text { with freedom of speech and } \\
\text { to increase awareness of } \\
\text { the brainprint media leaves } \\
\text { on audiences and society.' } \\
\text { Annual Review, 2015, p. } \\
28 \\
\text { 'Alma Media's response to } \\
\text { these challenges [in the } \\
\text { media sector] is sustainable } \\
\text { media that cultivates } \\
\text { traditional journalistic } \\
\text { values while integrating } \\
\text { broader corporate } \\
\text { responsibility in all } \\
\text { operations.' } \\
\text { Annual Review, 2015, p. } \\
28\end{array}$ & $\begin{array}{l}\text { 'In addition to the } \\
\text { economic, social and } \\
\text { ecological effects typical of } \\
\text { all entrepreneurial activity, } \\
\text { the activities of media } \\
\text { companies have direct and } \\
\text { indirect social and cultural } \\
\text { effects that are difficult to } \\
\text { measure but still } \\
\text { important.' } \\
\text { Sustainability website, } \\
\text { 2015 } \\
\text { 'In order to ensure } \\
\text { reliability, freedom of } \\
\text { speech and independence, } \\
\text { Alma Media’s digital } \\
\text { services, newspapers and } \\
\text { other operations not only } \\
\text { comply with laws and } \\
\text { regulations, but also apply } \\
\text { ethical self-regulation of } \\
\text { the media industry as well } \\
\text { as journalistic guidelines } \\
\text { and their own ethical } \\
\text { guidelines.' } \\
\text { Code of Conduct, } 2015\end{array}$ & $\begin{array}{l}\text {. open corporate } \\
\text { communications } \\
\text { · responsible influence \& } \\
\text { impact on society } \\
\text { (brainprint) } \\
\text { · assessment and } \\
\text { measurement of } \\
\text { environmental impacts } \\
\text { · integrating responsibility } \\
\text { into product and service } \\
\text { development } \\
\text { - incorporating } \\
\text { responsibility into the } \\
\text { daily choices of } \\
\text { employees }\end{array}$ \\
\hline
\end{tabular}




\begin{tabular}{ll}
\hline 'Brainprint is the impact of \\
the media content produced \\
through journalism. Thus, \\
it is strongly related to \\
responsible journalism and \\
its four dimensions: \\
supporting democracy, \\
ethically transparent \\
journalism, producing \\
utility for the readers and \\
defending and speaking for \\
the local community' \\
Sustainability website, \\
2015 \\
\hline
\end{tabular}

As Table 3 illustrates, not all the companies connected journalistic and business responsibilities in their corporate responsibility materials. Two companies, TS Group and Keskisuomalainen Group, defined their corporate responsibility only in relation to environmental issues. Whereas TS Group mentioned environmental issues and activities only briefly, Keskisuomalainen Group offered extensive and very detailed information and measurements of their environmental impacts and activities. Otava Group had a somewhat integrative approach, whereby the content that they produce was connected to the promotion of Finnish culture and language as well as learning and education. Sanoma Media and Alma Media integrated journalism ethics and business ethics as the basis for a holistic approach to corporate responsibility, highlighting the impact of media content on people and society.

The results of the analysis are presented below in greater detail by grouping the companies according to their views on corporate responsibility: 'dual thinkers' (Keskisuomalainen Group and TS Group), the ‘semi-integrative’ approach (Otava Group) and 'integrative forerunners’ (Sanoma Media and Alma Media Corporation).

\section{The dual thinkers: Keskisuomalainen Group and TS Group}

Keskisuomalainen Group produces print and digital media and offers marketing, research and printing services. Environmental management is at the forefront in Keskisuomalainen 
Olkkonen: Separation or integration of journalistic and business responsibilities

Group’s reporting - only environmental issues are mentioned in the annual review and on the corporate responsibility website, and the company publishes a separate environmental report. The environmental report gave extensive information about the Group’s environmental impact, the environmental management system and detailed data concerning, for example, material consumption, waste and recycling. Keskisuomalainen Group reported to constantly develop its environmental management system, which covers the whole corporation, and the analysed report implied that the company is currently expanding activities:

In the future, the current environmental issues of the corporation will include changes required by the ISO 14001 standard and reporting corporate responsibility. (Keskisuomalainen Group Environmental Report, 2015, p. 2).

Of the companies analysed, Keskisuomalainen Group covered environmental issues with the greatest amount of detail, but mentioned no other responsibility areas in their material.

TS Group focuses on newspaper publishing and printing services and engages in marketing communication, newspaper delivery, photo services and TV and radio broadcasting. In its annual review, TS Group only briefly mentioned environmental responsibility and issues related to it, such as material choices and recycling:

The production processes fulfil all environmental requirements. We take environmental aspects into consideration when selecting materials and constantly look for alternatives with less impact. Waste is sorted already at the sites and recycled for further use. (TS Group annual review, 2015, p. 12)

The annual review or the corporate website of TS Group did not include references to other responsibility issues, neither did they address the role of journalism ethics. Of the companies analysed, TS Group provided by far the least amount of information on its responsibilities.

Keskisuomalainen Group and TS Group represent a separated dual responsibility thinking in the sense that the analysed materials did not connect responsibilities related to 
Olkkonen: Separation or integration of journalistic and business responsibilities

journalism ethics to business responsibilities. The economic and environmental impacts of running a business were portrayed as separate to their journalistic operations, and the companies did not discuss the impact of journalistic content as part of their corporate (social) responsibility. The absence of journalistic responsibilities cannot be explained by the corporations' overall scope of activities: although these corporations do much more than journalism, Keskisuomalainen Group publishes 40 newspapers and TS Group publishes two newspapers and runs a radio station. Overall, the dual thinkers' view of corporate responsibility seemed to be rather narrow, as they did not discuss social responsibilities or impacts on their stakeholders or society. From the perspective of comprehensive corporate responsibility thinking, the dual thinkers omitted social issues, both in terms of sectorspecific issues relating to journalistic content, but also issues relating to employees and communities.

The semi-integrative approach: Otava Group

Otava Group publishes books and magazines and owns a large Finnish bookshop chain. On its corporate responsibility website, the group highlighted its long history as a family-owned enterprise and emphasised its role in fostering the Finnish language and culture. The Group presented its role as central for language and culture, as it publishes Finnish literature and educational materials that ultimately have an impact on how language and culture develop and how students are educated. The company stressed its approach to running the business with long-term goals as opposed to short-term profit and gains. As stated by the Chairman of the Board in the annual report:

The owners and the personnel remain committed to the objectives of long-term success. The basis of this commitment is our belief that reading will retain its status 
Olkkonen: Separation or integration of journalistic and business responsibilities

as a foundation block for Finnish well-being and success. (Otava annual report, 2015, p. 4)

With this statement, Otava Group made reference to how their aspiration to produce highquality products ultimately connects with maintaining the world-renowned Finnish education system. Furthermore, the company mentioned that, as part of its responsibility, it strives to contribute to the Finnish economy by prioritising Finnish family-owned suppliers. As Otava Group is one of the largest publishers in Finland, it gave considerable space to explaining the environmental impacts of printing books and magazines and how it aims to make its operations sustainable (e.g. by avoiding toxic glues and using certified paper). As such, Otava Group mostly addressed (social and environmental) responsibilities that do not relate to journalism. However, the company mentioned freedom of speech as the basis of their publishing operations. Furthermore, the guidelines for journalists (determined by the Council for Mass Media, 2014) that stress editorial independence and the environmental guidelines for the communication sector (determined by the Finnish Media Federation) were mentioned as guiding principles for the Group.

Otava Group’s approach can be categorised as a semi-integrative approach to journalism ethics and business ethics. The company did see its responsibilities holistically, as a combination of economic, social and environmental issues, and it acknowledged the impact of its products on individuals and society. However, beyond the (brief) references to freedom of speech and the guidelines for journalists, sector-based corporate responsibility issues relating to journalism ethics were largely absent from Otava Group’s material. A possible explanation could be that although Otava Group publishes magazines, it is mostly involved in publishing and printing books, which do not relate to journalistic production. 
Olkkonen: Separation or integration of journalistic and business responsibilities

The integrative forerunners: Sanoma Media and Alma Media Corporation

Sanoma Media produces printed magazines, newspapers, digital media, radio, television, and learning products. Besides Finland, Sanoma Media has operations in Belgium, the Netherlands, Poland and Sweden. In its Corporate Social Responsibility report, Sanoma Media took an integrated stance on its responsibilities, discussing journalism ethics and business ethics jointly. Sanoma Media recognises the impact of its products in the daily lives of millions of people and, therefore, highlighted the importance of producing high-quality content that helps consumers develop themselves and experience enjoyment. Resting on the democratic ideals of free speech and the watchdog role, Sanoma Media presented its business as inherently responsible.

Overall, Sanoma Media’s view of corporate responsibility was comprehensive, taking into account its journalistic responsibilities as well as responsibilities relating to running a business:

Our social impact is considerable. We have the power to raise awareness with our content, ramp up education with our learning solutions and provide work and prosperity in our operating countries. (Sanoma Media Corporate Social Responsibility website, 2015)

The Corporate Social Responsibility report of Sanoma Media discussed both general responsibility issues, such as environmental management (e.g. use of certified paper, emissions), supply chain management, talent and diversity management, and responsible business practices, and sector-based corporate responsibility issues, such as promoting democracy, impact of data privacy, learning and content impact and ethical journalism. In their Code of Conduct, Sanoma Media also addressed issues such as transparency of commercial content (advertising, product placements and paid editorials), anticorruption, employee rights and well-being, human rights and fair competition. In relation to ethical 
Olkkonen: Separation or integration of journalistic and business responsibilities

journalism, Sanoma Media further mentioned their internal guidelines for journalists that concern, for example, decision-making about journalistic content.

Alma Media Corporation focuses on digital services and publishing. Besides news content, Alma Media produces content on lifestyle, career and business. In its annual review, Alma Media described itself as a pioneer of corporate responsibility among Nordic media companies, an active developer of the sustainable media perspective, and a champion of the theme in public discussion. The annual review listed Alma Media’s goals and achievements in corporate responsibility, including issues relating to both general corporate responsibility (environmental management, stakeholder interaction) and sector-based corporate responsibility (responsible journalism, responsible advertising and marketing). In addition, employee issues, such as well-being, equality and human rights, were discussed in the annual review and the Code of Conduct. As a sector-based responsibility area, Alma Media focused especially on the 'brainprint', which describes the impact of media and their products on people and society. Alma Media described itself as a champion in raising awareness of the brainprint concept (originally launched by the WWF) and actively develops the integration and measurement of this concept in its operations:

Taking the brainprint of media into account in content production and journalism each day constitutes an important part of Alma Media's responsible business. One way to evaluate the success of Alma Media's papers is to monitor changes in the number of Council for Mass Media (CMM) decisions concerning Alma Media. Council for Mass Media (CMM) decisions, reader feedback, reader panels and requests for corrections are all metrics for reliability and responsible journalism. (Alma Media Annual Review, 2015, p. 38). 
Olkkonen: Separation or integration of journalistic and business responsibilities

Of the companies analysed, Alma Media is the only one that reportedly develops its responsibilities in close connection with partners, especially the Media CSR Forum and the Finnish Business \& Society network.

Based on their materials, Sanoma Media and Alma Media Corporation were clearly the forerunners in integrating journalism ethics and business ethics. They represented a holistic approach to corporate responsibility and addressed issues on a large spectrum, including sector-specific issues, issues with special implications and general responsibility issues. In their material, they discussed journalism ethics and business ethics in close relation to each other.

What strikes as considerably different in the forerunner companies' materials is that their holistic approach painted a comprehensive picture of the overall environment and network in which they operate as businesses, including interlinking economic, social, and environmental aspects. Furthermore, the forerunners explained how they address, evaluate and monitor their different responsibilities as entities that support each other. The forerunner role is even explicitly self-claimed by Alma Media, as it strives to serve as a role model for building business on the ethical and environmentally conscious production of journalistic content.

To summarise the results of the analysis, Figure 1 depicts the level of responsibility issues addressed by the dual thinkers, semi-integrative and forerunners. Figure 2 further explicates what issues were addressed by the corporations in terms of generic responsibility issues, issues with special implications for media companies and unique issues for media companies, which are further divided into economic, environmental, and social dimensions of corporate responsibility. 
Olkkonen: Separation or integration of journalistic and business responsibilities

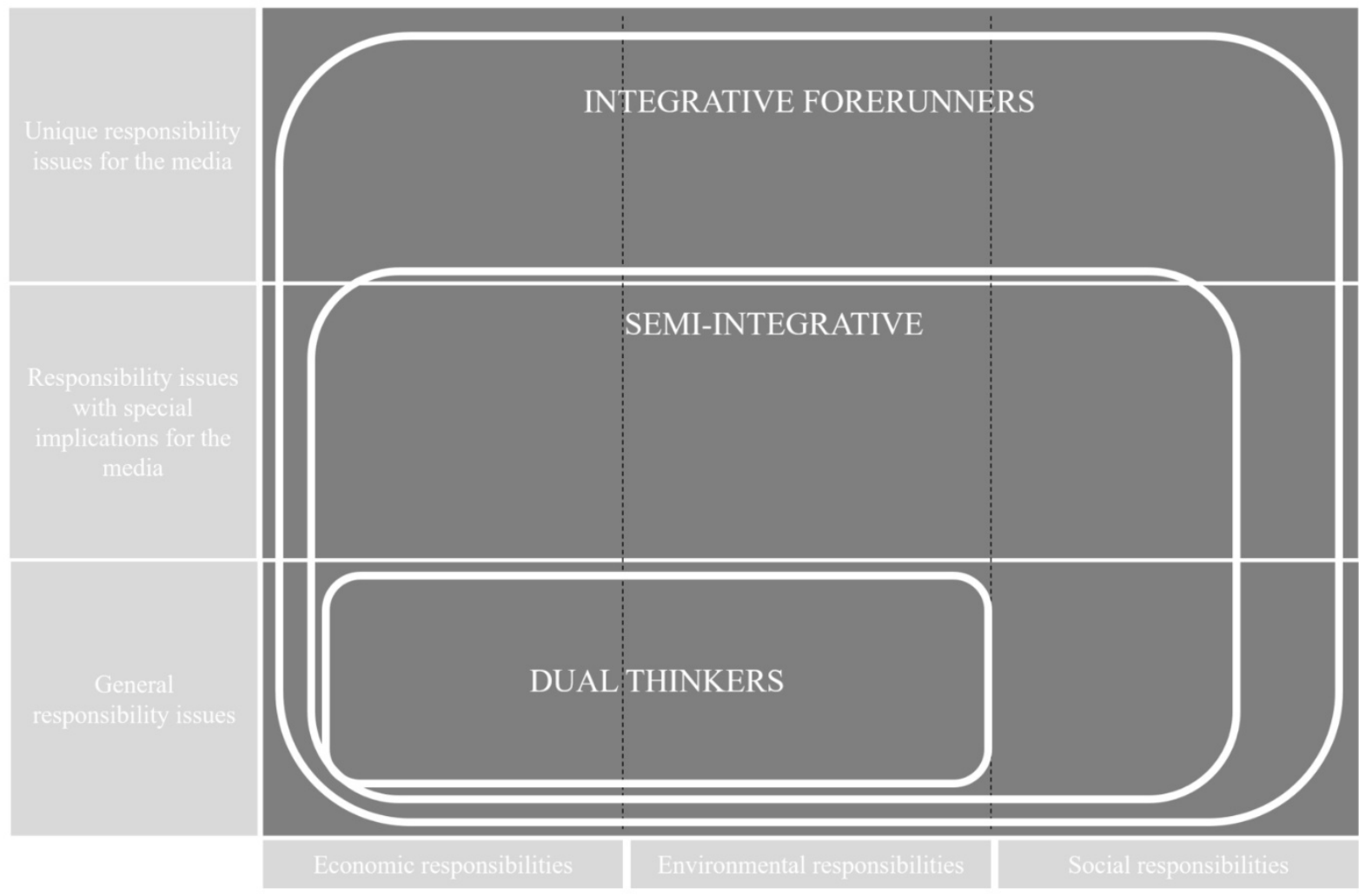

Figure 1. Level of Responsibility Issues Addressed by the Companies

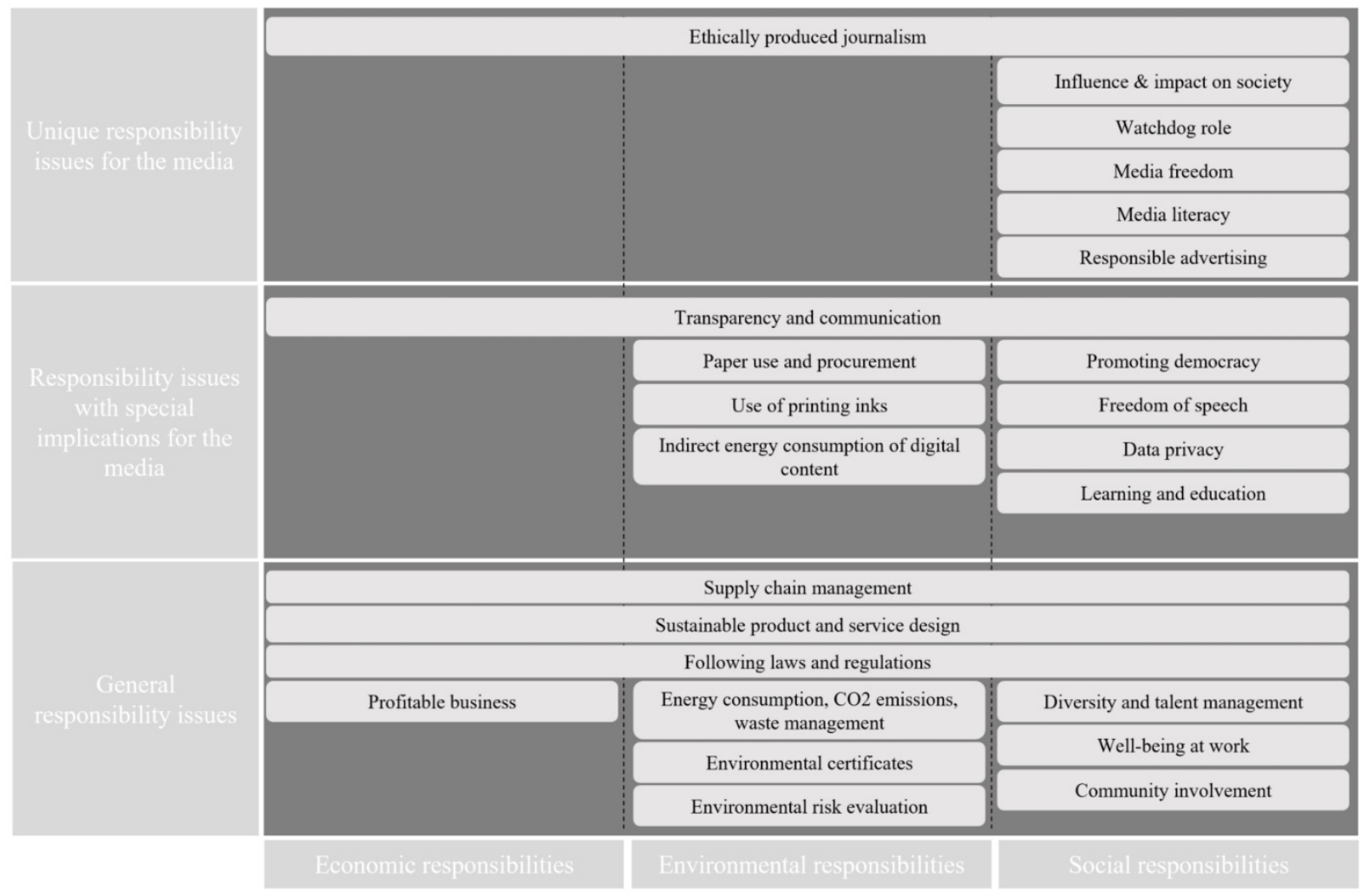

Figure 2. Examples of Responsibility Issues Addressed by the Companies 
Olkkonen: Separation or integration of journalistic and business responsibilities

The next section continues the discussion on the results and how they portray the separation and integrative arguments, along with their implications for media management.

\section{Discussion}

The purpose of this article was to examine how large Finnish media companies address corporate responsibility and whether the companies separate or integrate journalistic and business responsibilities in their corporate responsibility materials. Based on the analysis of five large Finnish media companies, the companies address corporate responsibility differently, depending on whether they follow the separation argument or have a more integrated stance on journalistic and business responsibilities. The dual thinkers separate journalistic responsibilities from (limited) business responsibilities by omitting journalistic responsibilities from their corporate responsibility material; the semi-integrator makes some connections with sector-specific responsibilities and journalistic content; and integrative forerunners comprehensively integrate journalistic and business responsibilities by addressing economic, environmental and social responsibilities as issues that deal with either generic corporate responsibility or sector-based corporate responsibility (unique issues or issues of special importance).

There can be several explanations for the differences between the companies. The companies can simply be at different stages in building their corporate responsibility strategies and systems-environmental issues are typically one of the first issues to be tackled and reported, largely because they are also (often) regulated by law, whereas the integration of more complex societal issues often come at later stages (see Mirvis \& Googins, 2006). Reporting can also become a question of resources; the forerunner companies, Sanoma Media and Alma Media, have in-house corporate responsibility managers, while the detailed work on environmental reporting by Keskisuomalainen Group is run by a quality and 
Olkkonen: Separation or integration of journalistic and business responsibilities

environmental director. As Karmasin and Bichler (2017) have recently noted, holistic approaches to corporate responsibility in media companies are rare to come by, even on a European scale, which is why the forerunners of this study might serve as examples beyond the Finnish context.

Another interpretation of the results can be that those companies reporting only on environmental issues followed the separation argument of responsibilities, as issues relating to journalism ethics were not reported in connection with business responsibilities. This view treats business ethics as mainly bearing financial responsibility to shareholders and running a business according to laws and regulations. Although especially Keskisuomalainen Group reported on environmental responsibility and had invested substantial amounts of resources to environmental management, its view of responsibility left out large areas of business ethics and general responsibility issues such as responsibility to employees (e.g. equal treatment, well-being) and the surrounding communities. Moreover, sector-based responsibility issues that cross editorial and business management were missing. Thus, although the environmental impacts, and the management of those impacts, can be very tangible and transparent, dual-thinking reporting includes considerable silences concerning the social impact of the core business. An example of an intersecting issue between journalistic and business responsibilities is media literacy, which Alma Media discussed as part of its responsibility and influence on society. With such intersecting issues, the forerunner companies were able to make meaningful connections between journalistic and business responsibilities and, essentially, extend journalistic responsibilities beyond professional norms and the work of an individual journalist to organisation-level policies.

One of the core ideas of corporate responsibility is that the actions of an organisation can be openly assessed by external parties and, thus, attempts to separate journalistic and business responsibilities and, consequently, transparently report only some of them can make 
Olkkonen: Separation or integration of journalistic and business responsibilities

media responsibility fuzzy and difficult to assess. Although media actors in democratic societies operate under unusually high self-regulation and serve an inherently societal role that, to some extent, has diminished the pressure to adopt corporate responsibility practices (Bachmann \& Ingenhoff, 2017), the media industry has become concentrated, more complex and thus more difficult to assess. In the materials used for this study, any stakeholder seeking information on ethical conduct would have been left uninformed about how dual-thinkers address journalism ethics. To some extent, the same applies to the semi-integrative example, as the company only addressed some sector-specific responsibilities. The forerunner companies not only portrayed a much more nuanced canvas of responsibilities, they also reported how they measure and evaluate their journalistic impact (examples from Alma Media: Council of Mass Media decisions, reader feedback, reader panels and requests for corrections).

Overall, the quest for more responsible business practices and more deliberate, positive societal impacts of business is on the rise (e.g., Scherer \& Palazzo, 2007). Thus, the intensifying expectations of corporate responsibility in the media industry are likely to be a persistent trend. By leaving out central areas of corporate responsibility, media organisations that follow the separation argument can lose important opportunities to create value and maintain credibility. In particular, succeeding in (holistic) corporate responsibility has been connected to the strengthening of intangible assets such as reputation, legitimacy and trust (see, e.g. Amaeshi \& Adi, 2007; Crane \& Glozer, 2016; Matten \& Moon, 2008). Although dual structures are a reality for media companies, external assessments of the credibility and legitimacy of media organisations do not necessarily follow dual lines: irresponsibility in one area is perceived as irresponsibility of the overall organisation (Olkkonen, 2015). This, consequently, calls for more research that looks beyond dual structures and assesses the actions of business entities as a whole. In other words, there is a need for research on 
Olkkonen: Separation or integration of journalistic and business responsibilities

corporate responsibility in the media sector that understands the big picture of media, business, ethics and responsibilities. This article has presented sector-based corporate responsibility as an approach that can incorporate these views.

As a limitation, this study focused on corporate reports that do not necessarily describe (all) actual actions. Moreover, the material used in this study focused on the viewpoint of the corporation, which can include much more than journalistic production (such as editing and publishing fictional books). The corporate view is a birds-eye view that can omit details. Therefore, research on actual practices can provide insight on journalism ethics and business ethics in individual media units as well as in different geographical and cultural settings.

Regarding the practice of media management, the study's holistic and integrative examples of corporate responsibility can illustrate how business ethics can support journalism ethics by weaving it into organisational-level policies and strategies. The forerunners addressed ethics and responsibilities as entities across editorial and business management, which is likely to be more consistent for stakeholders than isolating journalistic and business responsibilities in silos where they are not discussed together. A sector-based view to corporate responsibility of media organisations can thus help overcome the juxtapositioning of economic and ethical concerns in media companies, as a holistic approach to corporate responsibility does not view responsibility as an add-on (such as philanthropy), but as part of a company’s purpose and strategy. Moreover, sector-based corporate responsibility shows how media managers can make their actions more transparent for stakeholders to comprehensively assess and engage in corporate responsibility without compromising journalism ethics. Managing responsibility in media companies can involve fewer internal tensions and serve a more strategic role when it expands across the dual structures. 
Olkkonen: Separation or integration of journalistic and business responsibilities

\section{References}

Adams-Bloom, T., \& Cleary, J. (2009). Staking a claim for social responsibility: An argument for the dual responsibility model. The International Journal on Media Management, 11, 1-8.

Altmeppen, K.-D., Hollifield, C.A., \& van Loon J. (2017). Value-oriented media management: What, why, and what for? An introduction to this volume. In K.-D. Altmeppen, C.A. Hollifield, \& J. van Loon (Eds.), Value-oriented media management: Decision making between profit and responsibility (pp. 1-16). Cham: Springer.

Amaeshi, K. M., \& Adi, B. (2007). Reconstructing the corporate social responsibility construct in Utlish. Business Ethics: A European Review, 16(1), 3-18.

Bachmann, P., \& Ingenhoff, D. (2017). Finding common ground: CSR and media responsibility. In K.-D. Altmeppen, C.A. Hollifield, \& J. van Loon (Eds.), Value-oriented media management: Decision making between profit and responsibility (pp. 147-157). Cham: Springer.

Banerjee, S. B. (2008). Corporate social responsibility: The good, the bad and the ugly. Critical Sociology, 34(1), 51-79.

Christians, C., \& Nordenstreng, K. (2004). Social responsibility worldwide. Journal of Mass Media Ethics, 19(1), 3-28.

Commission on Freedom of the Press. (1947). A free and responsible press. A general report on mass communication: Newspapers, radio, motion pictures, magazines, and books. Chicago, IL: University of Chicago Press.

Council for Mass Media. (2014). Guidelines for journalists and an annex. Retrieved from http://www.jsn.fi/en/guidelines_for_journalists/.

Crane, A., \& Glozer, S. (2016). Researching corporate social responsibility communication: Themes, opportunities and challenges. Journal of Management Studies, 53(7), 1223-1252. 
Olkkonen: Separation or integration of journalistic and business responsibilities

Crane, A., \& Matten, D. (2007). Business ethics (2nd edition). Oxford: Oxford University Press.

Fairfield, J., \& Shtein, H. (2014). Big data, big problems: Emerging issues in the ethics of data science and journalism. Journal of Mass Media Ethics, 29(1), 38-51.

Ferrell, O.C., Fraedrich, J., \& Ferrell L. (2015). Business ethics: Ethical decision making and cases. Stamfort, CT: Cengage Learning.

Freeman, R. E. (2004). The stakeholder approach revisited. Zeitschrift für Wirtschafts- und Unternehmensethik, 5(3), 228-241.

Freeman, R.E. (1984). Strategic Management: A Stakeholder Approach. Boston: Pitman.

Gershon, R. A. (2017). The diffusion of authority: A case study analysis of News

Corporation’s News of the World newspaper. In K.-D. Altmeppen, C.A. Hollifield, \& J. van Loon (Eds.), Value-oriented media management: Decision making between profit and responsibility (pp. 189-207). Cham: Springer.

Global Reporting Initiative. (2018). Sector guidance. Retrieved from https://www.globalreporting.org/information/g4/sector-guidance/Pages/default.aspx Global Reporting Initiative. (2014). Sector disclosures: Media. Amsterdam: Global Reporting Initiative. Retrieved from https://www.globalreporting.org/resourcelibrary/GRI-G4-MediaSector-Disclosures.pdf

Global Reporting Initiative. (2013). Sustainability reporting guidelines: Reporting principles and standard disclosures. Amsterdam: Global Reporting Initiative. Retrieved from https://www.globalreporting.org/resourcelibrary/GRIG4-Part1-Reporting-Principles-andStandard-Disclosures.pdf

Grayson, D. (2009). Corporate responsibility and the media. The Doughty Centre for Corporate Responsibility. Cranfield: Cranfield School of Management. 
Olkkonen: Separation or integration of journalistic and business responsibilities

Gulyás, Á. (2011). Demons into angels? Corporate social responsibility and media organisations. Critical Survey, 3(2), 56-74.

Hayes, A. S., Singer, J. B., \& Ceppos, J. (2007). Shifting roles, enduring values: The credible journalist in a digital age. Journal of Mass Media Ethics, 22(4), 262-279.

Heikkilä, H., \& Kylmälä, T. (2011). Finland: Direction of change still pending. In T.

Eberwein, S. Fengler, E. Lauk, \& T. Leppik-Bork (Eds.), Mapping media accountabilityin Europe and beyond (pp. 50-62). Cologne: Halem.

Hou, J., \& Reber, B. H. (2011). Dimensions of disclosures: Corporate social responsibility (CSR) reporting by media companies. Public Relations Review, 37(2), 166-168.

Hsieh, H.-F., \& Shannon, S. E. (2005). Three approaches to qualitative content analysis. Qualitative Health Research, 15(9), 1277-1288.

Ingenhoff, D., \& Koelling, A. M. (2012). Media governance and corporate social responsibility of media organizations: An international comparison. Business Ethics: A European Review, 21(2), 154-167.

Jaehnig, W. B., \& Onyebadi, U. (2011). Social audits as media watchdogging. Journal of Mass Media Ethics, 26(1), 2-20

Karmasin, M., \& Bichler, K. (2017). Corporate social responsibility in the media industry: Setting the benchmark of falling behind? In K.-D. Altmeppen, C.A. Hollifield, \& J. van Loon (Eds.), Value-oriented media management: Decision making between profit and responsibility (pp. 135-146). Cham: Springer.

Karppinen, K., Nieminen, H., \& Markkanen, A.-L. (2011). Finland: Higher professional ethos in a small concentrated media market. In L. Nord, H. Nieminen, \& J. Trappel (Eds.), The media for democracy monitor: A cross national study of leading news media (pp. 113142). Gothenburg: Nordicom. 
Olkkonen: Separation or integration of journalistic and business responsibilities

Kauppalehti. (2017). Menestyjät [The Successful]. Retrieved from http://www.kauppalehti.fi/5/i/yritykset/menestyjat/lista.jsp?id=1\&maakunta=0\&kunta=0\&t oimiala $=21 \&$ sivu $=1 \&$ sortby=v1\&sort=desc .

Martin, H. J., \& Souder, L. (2009). Interdependence in media economics: Ethical implications of the economic characteristics of news. Journal of Mass Media Ethics, 24(23), 127-145.

Matten, D., \& Moon, J. (2008). “Implicit” and “explicit” CSR: A conceptual framework for a comparative understanding of corporate social responsibility. Academy of Management Review, 33(2), 404-424.

McIntyre, J. S. (1987). Repositioning a landmark: The Hutchins Commission and freedom of the press. Critical Studies in Mass Communication, 4(2), 136-160.

Media CSR Forum. (2008). Mapping the landscape: CSR issues for the media sector 2008. Retrieved from https://responsiblemediaforum.org/downloadDocumentFile?document=68 Mirvis, P., \& Googins, B. (2006). Stages of corporate citizenship. California Management Review, 48(2), 104-126.

Nygaard Blom, J., \& Reinecke Hansen, K. (2015). Click bait: Forward-reference as lure in online news headlines. Journal of Pragmatics, 76, 87-100.

Okoye, A. (2009). Theorising corporate social responsibility as an essentially contested concept: Is a definition necessary? Journal of Business Ethics, 89(4), 613-627.

Olkkonen, L. (2015). Audience enabling as corporate responsibility for media organizations. Journal of Media Ethics, 30(4), 268-288.

Peterson, T. (1956). The social responsibility theory. In F. S. Siebert, T. Peterson, \& W. Schramm (Eds.), Four theories of the press (pp. 73-104). Champaign, IL: University of Illinois Press. 
Olkkonen: Separation or integration of journalistic and business responsibilities

Raittila, P., Koljonen, K., \& Väliverronen, E. (2010). Journalism and school shootings in Finland 2007-2008. Tampere: Tampere University Press.

Reporters Without Borders. (2018). Finland. Retrieved from https://rsf.org/en/finland.

Reporters Without Borders. (2016). Reporters Without Borders (RSF) remains concerned about actions taken by national broadcaster Yle. Retrieved from:

https://rsf.org/en/news/reporters-without-borders-rsf-remains-concerned-about-actionstaken-national-broadcaster-yle.

Richards, I. (2004). Stakeholder versus shareholders: Journalism, business, and ethics. Journal of Mass Media Ethics, 19(2), 119-129.

Scherer, A. G., \& Palazzo, G. (2007). Toward a political conception of corporate responsibility: Business and society seen from a Habermasian perspective. Academy of Management Review, 32(4), 1096-1120.

Schrempf, J. (2012). The delimitation of corporate social responsibility: Upstream, downstream, and historic CSR. Business \& Society, 51(4), 690-707.

Stern, R. J. (2008). Stakeholder theory and media management. Ethical framework for news company executives. Journal of Mass Media Ethics, 23(1), 51-65.

Tate, W. L., Ellram, L. M., \& Kirchoff, J. F. (2010). Corporate social responsibility reports: A thematic analysis related to supply chain management. Journal of Supply Chain Management, 46(1), 19-44.

Tekes. (2009). Media 2009. Selvitys alan markkinatilanteesta ja trendeistä [Media 2009. A report on the state of the market and trends]. Helsinki: Tekes.

Timonen, L. \& Luoma-aho, V. (2010). Sector-based corporate citizenship. Business Ethics: A European Review, 19(1), 1-13. 
Olkkonen: Separation or integration of journalistic and business responsibilities

Wilenius, M., \& Malmelin, N. (2009). Towards sustainably managed media organizations: Reflections on the future of responsible business in media industry. Business Strategy Series, 10(3), 129-138.

Wring, D. (2012). 'It's just business': the political economy of the hacking scandal. Media, Culture \& Society, 34(5), 631-636. 